\title{
Anti-herpes simplex virus type 2 activity from Rhinacanthus nasutus (Linn.) Kurz. extracts as affected by different extraction solvents
}

\author{
Benchaluk Thongchuai ${ }^{1}$, Kongkiat Trisuwan' ${ }^{2}$, Sittiruk Roytrakul $^{3}$, \\ Yingmanee Tragoolpua ${ }^{4^{*}}$, and Padchanee Sangthong ${ }^{2,5^{*}}$
}

\begin{abstract}
${ }^{1}$ Interdisciplinary Program in Biotechnology, Graduate School, Chiang Mai University, Chiang Mai 50200, Thailand

${ }^{2}$ Department of Chemistry, Faculty of Science, Chiang Mai University, Chiang Mai 50200, Thailand

${ }^{3}$ National Center for Genetic Engineering and Biotechnology (BIOTEC), Pathum Thani 12120, Thailand

${ }^{4}$ Department of Biology, Faculty of Science, Chiang Mai University, Chiang Mai 50200, Thailand

${ }^{5}$ Research Center on Chemistry for Development of Health Promoting Products from Northern Resources, Chiang Mai University, Chiang Mai 50200, Thailand

*Corresponding authors.E-mail:padchanee.sangthong@cmu.ac.th;yingmanee.t@cmu.ac.th https://doi.org/10.12982/CMUJNS.2019.0002
\end{abstract}

Received: April 1, 2018

Revised: June 21, 2018

Accepted: July 13, 2018

\begin{abstract}
Rhinacanthus nasutus (Linn.) Kurz. is a medicinal plant traditionally used in northern Thailand. It has anti-bacterial, anti-inflammatory, anti-cancer, and anti-viral properties. This study investigated the anti-herpes simplex virus type 2 (anti-HSV2) activity of stem extracts of R. nasutus (Linn.) Kurz. on American green monkey kidney (or Vero) cells. The plant extracts were prepared with six different solvents: ethanol, ethylacetate, methanol, dichloromethane, acetone and hexane. The cytotoxicities of the stem extracts were determined using MTT assay with various concentrations of the stem extracts (2.44 to $156 \mu \mathrm{g} / \mathrm{mL})$ and the $50 \%$ cytotoxicity dose $\left(C D_{50}\right)$ was calculated after the Vero cells were treated with the stems extracts for $24 \mathrm{~h}$. The methanolic extract showed a low cytotoxicity on the Vero cells, with a $C D_{50}$ value of $78.22 \pm 23.54 \mu \mathrm{g} / \mathrm{mL}$; in contrast, the ethylacetate, dichloromethane, acetone and hexane extracts were highly toxic to the Vero cells. The anti-HSV2 activities of the plant extracts were investigated by plaque reduction assay after treating the infected Vero cells for $24 \mathrm{~h}$ with the stem extracts at concentrations between 2.44 and $19.50 \mu \mathrm{g} / \mathrm{mL}$. The inhibitory effect values of the $50 \%$ effective dose $\left(E D_{50}\right)$ were determined. The methanolic extract had the highest inhibitory effect $\left(E D_{50}\right.$ of $16.16+10.83$ $\mu \mathrm{g} / \mathrm{mL}$ ) against $\mathrm{HSV}-2$ infections and inhibited $\mathrm{HSV}-2$ particles by $70.5 \%$ after $24 \mathrm{~h}$ of
\end{abstract}


treatment. Our results showed the potential for using methanolic extracts from the stem of R. nasutus (Linn.) Kurz. to treat HSV2 infections during the late stage viral life cycle $24 \mathrm{~h}$ after infection.

Keywords: Anti-herpes simplex virus type 2 activity, Cytotoxicity, Rhinacanthus nasutus (Linn.) Kurz.

\section{INTRODUCTION}

Herpes simplex virus (HSV) is a single, large, double-stranded DNA virus that infects humans; it is widespread among the world's population, including in Thailand. Both herpes simplex virus type 1 (HSV-1) and type 2 (HSV-2) are members of the family Herpesviridae. HSV infects and replicates in human cells at the site of entry, especially mucocutaneous surfaces. The virus infects into the cell bodies of neurons in the sensory ganglion, damaging the infected sensory neurons. HSV-1 infection is a common cause of infections of the oral facial mucosal surfaces. HSV-2, or genital herpes, is the most common cause of genital ulcers (Yoosook et al., 1999; Yang et al., 2005; Koch et al., 2008). HSV is also an important cause of neonatal infections (Schomogyi et al., 1998; Reynolds et al., 2003; Straface et al., 2012). The HSV-2 genome is separated into long and short regions of unique sequences, termed $\mathrm{U}_{\mathrm{L}}$ and $\mathrm{U}_{\mathrm{S}}$ (Dolan et al., 1998; Taylor et al., 2002; Antrobus et al., 2009). The $155 \mathrm{~kb}$ genome of HSV-2 consists of two regions of unique sequences with a $\mathrm{G}+\mathrm{C}$ content of $70.4 \%$. The viral DNA encodes 74 gene products (Dolan et al., 1998).

Acyclovir (ACV) and other nucleoside derivatives, such as penciclovir, famciclovir, valaciclovir and ganciclovir, have been approved for HSV-1 and HSV-2 treatment. However, resistance to acyclovir and its analogs can occur following mutation in either HSV thymidine kinase or DNA polymerase, although the emergence of acyclovir-resistant strains of HSV appears to be infrequent in immunologically normal individuals (Whiteley et al., 1998; Stanberry et al., 1999). The potential for resistant strains and the high cost of treating HSV have led to seeking alternative treatments using medicinal plants. Many medicinal plants that have been shown to contain anti-herpes simplex viral activities, and used in traditional herpes treatments, are indigenous to Southeast Asia, including Thailand; these include Punica granatum, Ocimum sanctum, Azadirachta indica, Nyctanthes arbortristis, and Rhinacanthus nasutus (Linn.) Kurz. (Bourne et al., 1999; Yoosook et al., 1999; Yoosook et al., 2000; Yang et al., 2005; Xiong et al., 2011; Nakama et al., 2012). We focused on Rhinacanthus nasutus (Linn.) Kurz. due to its therapeutic effects, including anti-fungal, anti-bacterial, anti-tumor, hepatoprotective and anti-inflammatory activities (Kumar et al., 2012). R. nasutus (Linn.) Kurz is known as Thong Pan Chung in Thai. It is a small slender shrub, erect, branched and 1-2 m in height. R. nasutus (Linn.) Kurz. is widely spread across sub-continental Asia, including parts of India, China and Southeast Asia. The phytochemistry and biology of $R$. nasutus (Linn.) Kurz. have been extensively investigated. Major constituents include flavonoids, steroids, terpenoids, anthraquinones, lignin groups and, especially, napthoquinones, such as rhinacanthins (A-D, G-Q) (Suman et al., 2011). The objective of the current study was to evaluate the cytotoxicity and anti-HSV-2 activity of stem extracts from $R$. nasutus (Linn.) Kurz. using ethanol, methanol, ethylacetate, dichloromethane, acetone and hexane as extraction solvents on an American green monkey kidney cell line (Vero cell) model. 


\section{MATERIALS AND METHODS}

\section{Plant materials and genetic analysis}

The stems of $R$. nasutus (Linn.) Kurz. were obtained from Lampang Herb Conservation, Lampang Province, Thailand. A voucher specimen was also kept in the Lampang Herb Conservation. To analyze the genetics of the plant, total DNA of fresh leaves from plant samples was grinded to dried powder using liquid nitrogen and mortar, as described in Kunsorn et al. (2013). Then, DNA was extracted using a NucleoSpin ${ }^{\circledR}$ Plant II Kit and the quality of the DNA was analyzed by $0.8 \%(\mathrm{w} / \mathrm{v})$ agarose gel electrophoresis. The plant DNA was used as the DNA template in a polymerase chain reaction (PCR) to amplify intergenic spacer regions. Intergenic spacer regions are non-coding regions of chloroplast DNA. This study used intergenic spacer regions between $\operatorname{trnL-trnL}$ and $t r n L$-trnF. The PCR primers for these regions are shown in Table S1. The PCR amplification mixtures $(25 \mu \mathrm{L})$ contained 7.5 $\mu \mathrm{L}$ of DNA template; $2.5 \mu \mathrm{L}$ of $10 \mu \mathrm{M}$ of C, D, E and F primers; and $12.5 \mu \mathrm{L}$ of REDTaq ${ }^{\circledR}$ ReadyMix $^{\mathrm{TM}}$ (Taq polymerase) from Sigma-Aldrich. The amplified conditions were as follows; initial denaturation at $94^{\circ} \mathrm{C}$ for $2 \mathrm{~min}$; followed by 30 cycles of $94^{\circ} \mathrm{C}$ denaturation for $30 \mathrm{sec}$, $55^{\circ} \mathrm{C}$ annealing for $30 \mathrm{sec}$, and $72^{\circ} \mathrm{C}$ extension for $2.30 \mathrm{~min}$; then a final extension at $72{ }^{\circ} \mathrm{C}$ for $5 \mathrm{~min}$. The PCR products were determined by $1 \%(\mathrm{w} / \mathrm{v})$ agarose gel electrophoresis and visualized under UV transilluminator. Then, the PCR products were purified using NucleoSpin ${ }^{\circledR}$ Gel and PCR Clean-up Kit (Macherey-Nagel, Germany) before nucleotide sequence analysis by Dye terminator. Finally, all of the nucleotide sequences were compared to the GenBank ${ }^{\circledR}$ database (http://www.ncbi.nlm.nih.gov/genbank/).

Table S1. Nucleotide sequences of trnL-trnL and $\operatorname{trn} L$-trnF primers that were used for R. nasutus (Linn.) Kurz. genetic analysis.

\begin{tabular}{llc}
\hline Primer name & Nucleotide sequences $\left(\mathbf{5}^{\prime} \rightarrow \mathbf{3}^{\prime}\right)$ & Intergenic spacer regions \\
\hline Forward primer C & CGAAATCGGTAGACGCTACG & trnL-trnL \\
Reverse primer D & GGGGATAGAGGGACTTGAAC & \\
Forward primer E & GGTTCAAGTCCCTCTATCCC & trnL-trnF \\
Reverse primer F & ATTTGAACTGGTGACACGAG & \\
\hline
\end{tabular}

\section{Preparation of plant extracts}

The powdered stems of $R$. nasutus (Linn.) Kurz. were soaked in six different solvents, $95 \%$ ethanol, ethylacetate, $95 \%$ methanol, dichloromethane, acetone and hexane, for 7 days at room temperature with the ratio of plant and solvent as 50:250 $(\mathrm{g} / \mathrm{mL})$. Then, the suspensions of plant extracts were filtered and the solvents evaporated by rotary evaporator and the extracts dried with lyophilizer. The dry powder was dissolved in dimethylsulfoxide (DMSO) before investigating anti-herpes simplex virus type-2 (HSV-2) activity and cytotoxicity. 


\section{Cells and viral cultivation}

African green monkey kidney cells (Vero cells, ATCC ${ }^{\circledR}$ CCL- $81^{\mathrm{TM}}$ ) were grown in Eagle's minimum essential medium (EMEM) supplement with inactivated $10 \%$ fetal bovine serum and $10 \mu \mathrm{g} / \mathrm{mL}$ penicillin-streptomycin $\left(\mathrm{Gibco}^{\circledR}\right.$, England). The cell lines were incubated at $37^{\circ} \mathrm{C}$ in a humidified atmosphere with $5 \% \mathrm{CO}_{2}$. This study used the herpes simplex virus type 2 strain G. The HSV-2 was inoculated in Vero cells. The virus titer was performed using a plaque reduction assay and expressed as plaque forming unit per milliliter (PFU/mL). Virus stocks were stored at $-80^{\circ} \mathrm{C}$ until use.

\section{Cytotoxicity of $\boldsymbol{R}$. nasutus (Linn.) Kurz. extracts}

The cytotoxicity of all plant extracts was tested by MTT assay (Mossman, 1983). Firstly, Vero cells were seeded in 96-well plates at a concentration of $1 \times 10^{4}$ cells per well and incubated at $37^{\circ} \mathrm{C}$ in a humidified atmosphere with $5 \% \mathrm{CO}_{2}$ for $24 \mathrm{~h}$. After that, the cells were incubated with various concentrations of crude extracts of $R$. nasutus (Linn.) Kurz. using the six different solvents for $72 \mathrm{~h}$ at $37^{\circ} \mathrm{C}$ in a humidified atmosphere with $5 \% \mathrm{CO}_{2}$. The yellow tetrazolium MTT (3-(4, 5-dimethylthiazolyl-2)-2, 5-diphenyltetrazolium bromide) was reduced by dehydrogenase enzymes in active cells, to generate reducing equivalents, such as NADH and NADPH. Cellular viability was assayed by measuring the solubilized purple formazan product. Finally, the absorbance was measured using multi-detection plate reader at a wavelength of $540 \mathrm{~nm}$ and a reference wavelength of $630 \mathrm{~nm}$. The percentage cell viability was calculated using the formula:

$$
\% \text { cell viability }=\frac{(\text { Average absorbanace of triplicate untreated wells }- \text { treated wells })}{\text { Average absorbanace of triplicate untreated wells }} \times 100
$$

A dose-response curve was plotted to calculate the concentration of the $50 \%$ cell viability of the Vero cells.

\section{Antiviral activity of $\boldsymbol{R}$. nasutus (Linn.) Kurz. extracts against HSV-2}

The antiviral activity of $R$. nasutus (L.) Kurz. extracts against HSV-2 was evaluated by plaque reduction assay, as described in Chaliewchalad et al., 2013. Vero cells were seeded onto 6-well culture plates at a density of $3 \times 10^{6}$ cells per $\mathrm{mL}$ and incubated for $24 \mathrm{~h}$ at $37^{\circ} \mathrm{C}$ in a humidified atmosphere with $5 \% \mathrm{CO}_{2}$. The culture medium was removed and the cell monolayer was infected with a virus suspension to yield 100 plaques per well in the presence of various concentrations of six different solvent extracts of $R$. nasutus (Linn.) Kurz. and ACV (at concentrations of 3.1, 6.3, 12.5, 25, and $50 \mu \mathrm{g} / \mathrm{mL}$ ). The virus was allowed to be adsorbed for $1 \mathrm{~h}$ at $25^{\circ} \mathrm{C}$, then the cells were overlaid with an overlay medium containing $0.5 \%$ of methylcellulose and dilutions of R. nasutus (Linn.) Kurz. The plate was incubated for $72 \mathrm{~h}$ at $37^{\circ} \mathrm{C}$ in a humidified atmosphere with $5 \% \mathrm{CO}_{2}$. After that, the overlay medium was removed, and the infected cell monolayer was washed with PBS. Finally, the virus plaques formed on Vero cells were stained with $0.2 \%(\mathrm{w} / \mathrm{v})$ crystal violet. The number of plaques of extract-treated cells was compared with untreated controls. The inhibitory effect values of $50 \%$ effective dose $\left(\mathrm{ED}_{50}\right)$ were determined. 


\section{RESULTS}

Identification of $\boldsymbol{R}$. nasutus (Linn.) Kurz.

Rhinacanthus nasutus, commonly known as snake jasmine, is a member of the family Acanthaceae, subfamily Acanthoideae, and genus Rhinacanthus (Figure 1). However, the phytomorphology of $R$. nasutus (Linn.) Kurz. and Rhinacanthus gracilis are very similar. To identify the plant species, nucleotide sequences of $\operatorname{trn} L-\operatorname{trn} L$ and $\operatorname{trn} L-\operatorname{trn} F$, which are intergenic spacer regions in chloroplast DNA (cpDNA), were determined using Dye terminator method. After PCR amplification, PCR products of approximately 400 and $550 \mathrm{bp}$ in length were generated when using $\operatorname{trn} L-\operatorname{trn} L$ and $\operatorname{trn} L-\operatorname{trn} F$ primers. The nucleotide sequences of the $t r n L-t r n L$ and $t r n L-t r n F$ intergenic spacers are shown in Figure $2 \mathrm{~A}$ and B. According to the results, nucleotide sequence analysis of $R$. nasutus (Linn.) Kurz. CMU01 showed 100\% homology with $R$. nasutus (Linn.) Kurz. and 98\% homology with $R$. gracilis.

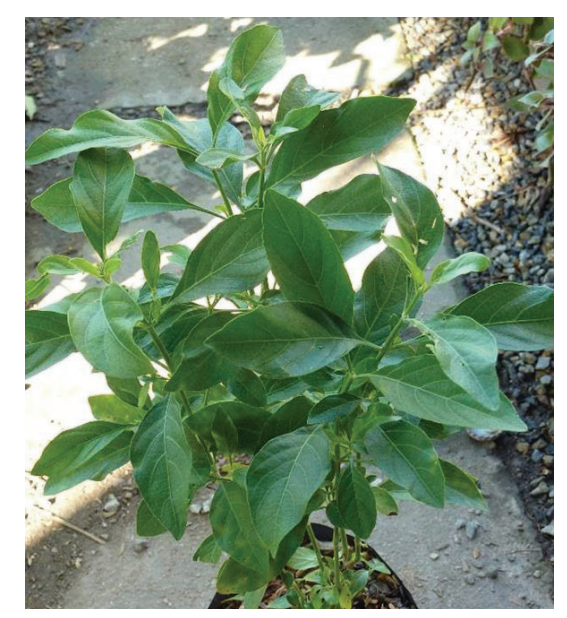

Figure 1. Rhinacanthus nasutus (Linn.) Kurz tree 
A) $\operatorname{trn} L$-trnL intergenic spacer

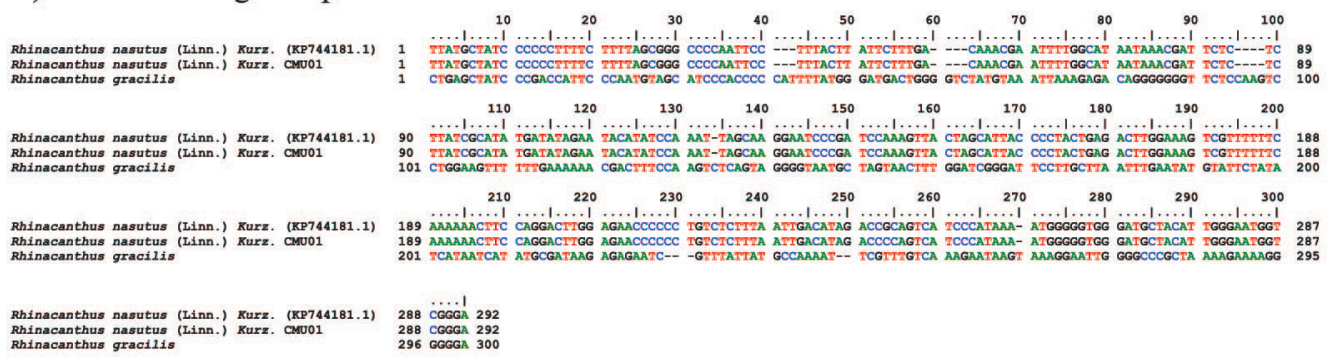

B) $\operatorname{trnL}$-trnF intergenic spacer

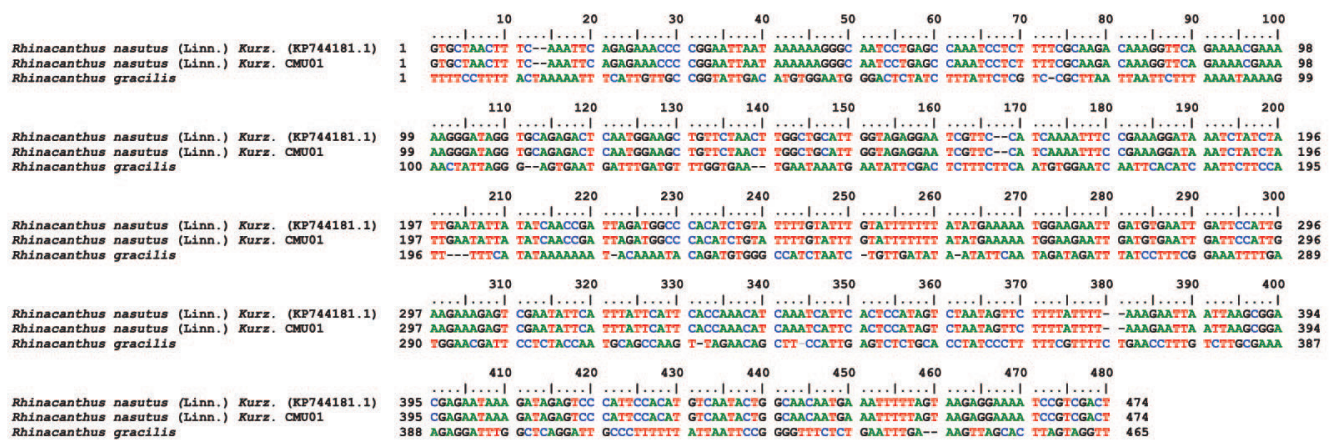

Figure 2. Comparison of nucleotide sequences in $\operatorname{trnL}$-trnL (A) and $\operatorname{trnL}$-trnF (B) intergenic spacers from Rhinacanthus nasutus (Linn.) Kurz. (KP744181.1), Rhinacanthus nasutus (Linn.) Kurz. CMU01 and Rhinacanthus gracilis.

\section{Cytotoxicity of the stem extracts of $\boldsymbol{R}$. nasutus (Linn.) Kurz.}

The cytotoxic effect of stem extracts from R. nasutus (Linn.) Kurz. by different six solvents was determined using MTT assay. In Table 1, the cytotoxic doses which expressed as $50 \%$ cytotoxicity dose $\left(\mathrm{CD}_{50}\right)$ of the stem extracts on American kidney monkey cell line (Vero cells). According to their $\mathrm{CD}_{50}$ toward the Vero cell, the acetone, hexane, dichloromethane and ethylacetate extracts of $R$. nasutus (Linn.) Kurz. showed more toxic than the ethanolic and methanolic extracts. On the other hand, the methanolic extract showed the least toxicity as its $\mathrm{CD}_{50}(78.22+1.3 \mu \mathrm{g} / \mathrm{mL})$.

\section{Antiviral activity of $\boldsymbol{R}$. nasutus (Linn.) Kurz. against HSV-2}

The antiviral activity of the R. nasutus (Linn.) Kurz. stem extract against HSV2 was demonstrated. The methanolic extract showed efficient inhibitory effects against HSV-2 particles with high percentage of inhibition of $70.50 \%$ after $24 \mathrm{~h}$ of treatment at the concentration of $19.50 \mu \mathrm{g} / \mathrm{mL}$ (Table 1, Figure 3). In addition, the inhibitory effect of a $50 \%$ effective dose $\left(\mathrm{ED}_{50}\right)$ and therapeutic index (TI value) of methanolic extract was $16.17 \pm$ $1.08 \mu \mathrm{g} / \mathrm{mL}$ and $4.81+0.51$. In contrast, the ethanolic and ethylacetate extracts of the $R$. nasutus (Linn.) Kurz. showed the HSV-2 infections at low concentrations (1.62 \pm 0.10 and 
$2.08 \pm 0.27 \mu \mathrm{g} / \mathrm{mL}$, respectively) whereas TI values were higher than the methanolic extract. According to the cytotoxicity dose, $\mathrm{ED}_{50}$ and TI value, we found that the methanolic extract of R. nasutus (Linn.) Kurz. showed the potential HSV-2 inhibitory activity when compared with other solvent extractions. After infected Vero cells were treated with methanolic stem extract of R. nasutus (Linn.) Kurz., the infected Vero cells decreased the cytopathic effect (CPE) compared with infected cells (Figure 4). These results indicated the methanolic extract of $R$. nasutus (Linn.) Kurz. contained many active compounds with a synergistic effect, resulting in its virucidal effect on HSV-2 infected cells.

Table 1. $50 \%$ cytotoxic dose $\left(\mathrm{CD}_{50}\right)$ and $50 \%$ effective dose $\left(\mathrm{ED}_{50}\right)$ of the stem extracts of R. nasutus (Linn.) Kurz. on Vero cells after viral attachment. (The values are expressed as mean $+\mathrm{SD}$ )

\begin{tabular}{|c|c|c|c|}
\hline Extraction solvents & $\begin{array}{c}\mathrm{CD}_{50} \\
(\mu \mathrm{g} / \mathrm{mL})\end{array}$ & $\begin{array}{c}\mathbf{E D}_{50} \\
(\mu \mathrm{g} / \mathrm{mL})\end{array}$ & TI value \\
\hline Ethanolic extract & $42.87 \pm 9.07$ & $1.62 \pm 0.10$ & $26.68 \pm 6.64$ \\
\hline Methanolic extract & $78.22 \pm 13.38$ & $16.17 \pm 1.08$ & $4.81 \pm 0.51$ \\
\hline Ethylacetate extract & $23.68 \pm 8.28$ & $2.08 \pm 0.27$ & $11.24 \pm 2.63$ \\
\hline Dichloromethane extract & $23.29 \pm 7.11$ & $<9.75$ & - \\
\hline Acetone extract & $21.85 \pm 6.65$ & $<9.75$ & - \\
\hline Haxane extract & $22.28 \pm 6.13$ & $<2.44$ & - \\
\hline Acyclovir (HSV drug) & $-{ }^{\mathrm{a}}$ & $13.83 \pm 1.88$ & - \\
\hline
\end{tabular}

Note: $\mathrm{ED}_{50}$ and $\mathrm{CD}_{50}$ were expressed as the mean \pm standard deviation (SD) of triplicate experiments; TI value $=$ Therapeutic index $\left(\mathrm{CD}_{50} / \mathrm{ED}_{50}\right)$; Data were expressed as mean \pm standard deviation $(\mathrm{SD})$ of triplicate experiments; ${ }^{\mathrm{a}}$ - Not determined. 


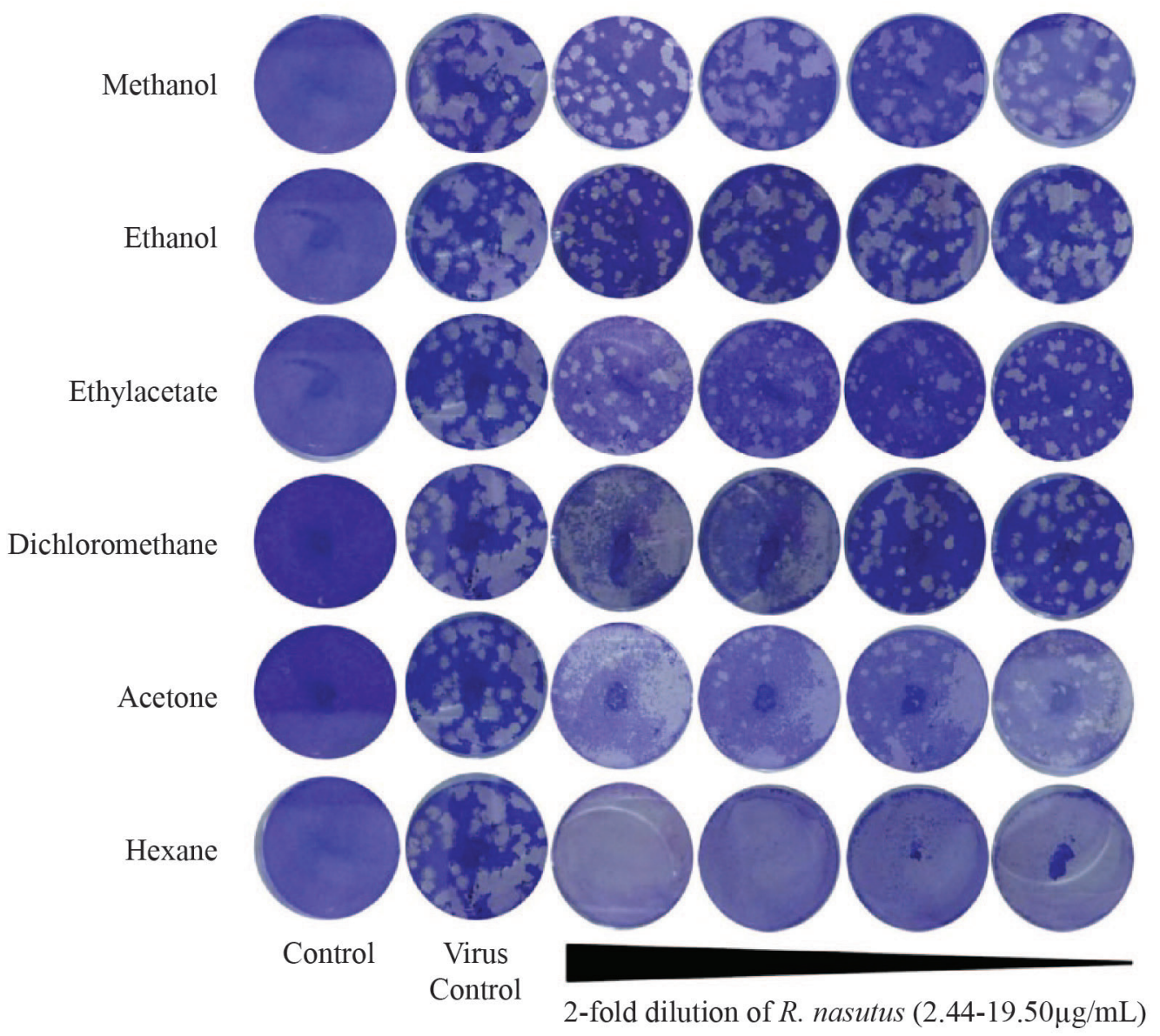

Figure 3. Plaque reduction assay and the effective dose $\left(\mathrm{ED}_{50}\right)$ of the various solvent extracts of $R$. nasutus (Linn.) Kurz. between 2.44 and $19.50 \mu \mathrm{g} / \mathrm{mL}$. 


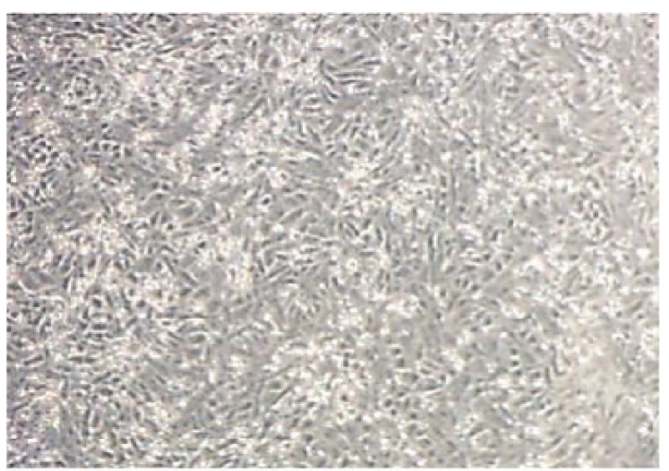

A

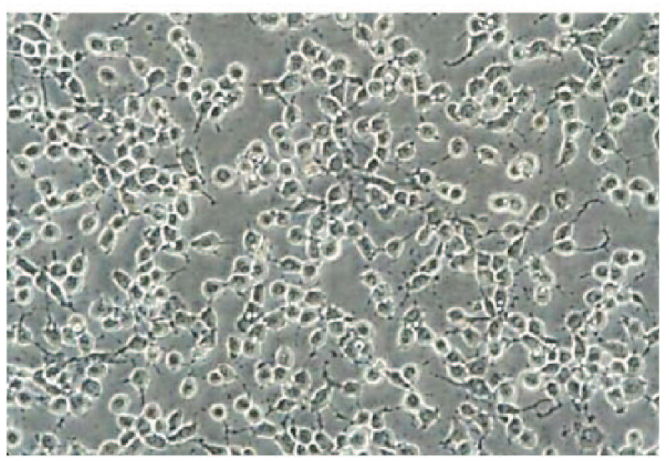

C

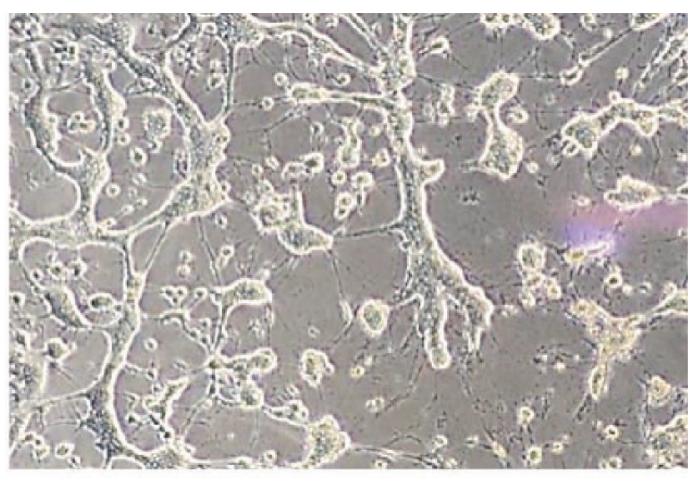

B

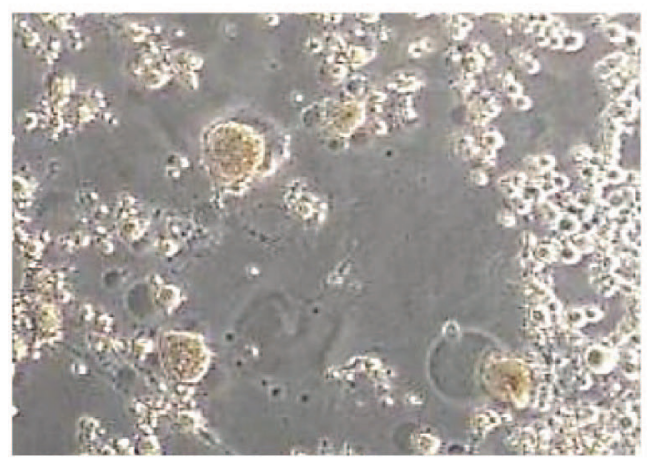

$\mathrm{D}$

Figure 4. Cell morphology of HSV-2 infected cells compared to treated cells after $24 \mathrm{~h}$ of treatment. Treated cells showed a decreased cytopathic effect. (A) Control cells, (B) virus control cells, (C) methanolic extract of $R$. nasutus extract treated cells and (D) Vero cells were killed by HSV-2.

\section{DISCUSSION}

In this study, the objective is to investigate the anti-HSV2 activity of $R$. nasutus (Linn.) Kurz., which is a medicinal plant that found in northern Thailand. To identify the genus and spices of the plant, nucleotide sequencing of chloroplast DNA (cpDNA) were determined. Using the $\operatorname{trn} L-\operatorname{trn} L$ and $\operatorname{trn} L-\operatorname{trn} F$ region which are intergenic spacer regions in chloroplast DNA for identification of $R$. nasutus (Linn.) Kurz. are successfully performed. Rhinacanthus nasutus belongs to the family Acanthaceae, subfamily Acanthoideae. McDade et al. (2000) studied the phylogenetic relationships within the large tropical and subtropical family Acanthaceae using genetic information from the nuclear ribosome internal transcribed spacer (nr-ITS) region, both alone and in combination with genetic information from the intron and spacer of the trnL-trnF chloroplast (cp) region. In addition, McDade et al., 2005 evaluated the phylogenetic relationships within the Acanthaceae using nucleotide sequences from four 
different regions: nrITS, the chloroplast, rps 16 intron, $\operatorname{trn} \mathrm{G}-\mathrm{S}$ spacer, and $\operatorname{trn} \mathrm{L}-\mathrm{F}$ intron and spacer. Cell viability and cytotoxicity tests are designed to determine the toxicity to cells of compounds or drugs either qualitatively or quantitatively. In this study, cytotoxicity of the stem extracts of $R$. nasutus (Linn.) Kurz. were determined by MTT assay. It was found the methanolic extract exhibited cytotoxicity on Vero cells which was lower than the cytotoxicity of the ethylacetate, dichloromethane, acetone, hexane and ethanolic extracts, as the evident from the $\mathrm{CD}_{50}$ values. The percentages of inhibition of the methanolic extract on HSV-2 was quite high. Hence, the inhibition of the methanolic extract was found after the viral infection process.

In previous reports, methanol was reported as a suitable solvent for isolating the active components from R. nasutus (Rao et al., 2013). Brimson et al. (2011) has shown that the root extract of $R$. nasutus prevented the hyotoxic conditions from HT-22 cell death by reducing the production of reactive oxygen species (ROS). Moreover, HSV infections generated reactive oxygen species (ROS) and reactive nitrogen species (RNS), resulting in oxidative stress in the infected cells (Mathew et al., 2010). In addition, HSV has been shown to degrade proteins in cells it infects by viral proteases. Chaliewchalad et al. (2013) investigated the inhibitory effect of $R$. nasutus (Linn.) Kurz. and Stemona tuberose (Lour.) whole extracts on herpes simplex virus infection and found that the $50 \%$ cytotoxic doses $\left(\mathrm{CD}_{50}\right)$ of aqueous extracts of $R$. nasutus and $S$. tuberose were $1,268.0$ and $5,677.0 \mu \mathrm{g} / \mathrm{mL}$, respectively. The aqueous extract of $R$. nasutus inhibited HSV-2 with a therapeutic index value of $4.16 \pm 0.02$. Ethanolic extracts of $R$. nasutus and S. tuberose inhibited HSV-2 particles by $95.12 \pm 1.43$ and $94.11 \pm$ $1.43 \%$, respectively, at $4 \mathrm{~h}$ of treatment. Brimson et al. (2012) demonstrated the antioxidant properties of ethanolic extracts of $R$. nasutus leaves and roots. Kumar et al. (2011) found that methanolic extracts of $R$. nasutus (Linn.) Kurz. showed potent anti-ulcer activity. In addition to $R$. nasutus (Linn.) Kurz., other substances have shown anti-HSV-2 activity, including essential oils, sandalwood oil, and propolis extracts (Benencia et al., 1999, Koch et al., 2008, Nolkemper et al., 2010). Both Barleria lupulina Lindl. and Clinacanthus nutans (Burm. F.) Lindau, in the family Acantaceae, are well known in Thai folk medicine. Yoosook et al. (1999) investigated the methanol extracts of these two plants against herpes simplex virus type 2 strain G, HSV-2(G). Yoosook et al. (2000) reported that crude water extracts of the Thai medicinal plants Centella asiatica L., Maclura cochinchinensis Cornor, and Mangifera indica L. contained both anti-HSV-1 and HSV-2 activities; a mixture of $C$. asiatica and $M$. indica showed an additive anti-HSV effect. Yang et al. (2005) reported that acetone, ethanol, and methanol extracts of Phyllanthus urinaria inhibited HSV-2 infections by disturbing the early stage of virus infection; the $50 \%$ inhibitory concentration $\left(\mathrm{IC}_{50}\right)$ against $\mathrm{HSV}-2$ infection of acetone, ethanol, and methanol extracts were $4.3+0.5,5.0+0.4$, and $4.0+0.9 \mu \mathrm{g} / \mathrm{mL}$, respectively. In summary, we have documented that a methanolic extract of $R$. nasutus (Linn.) Kurz. showed strong HSV-2 inhibition activity and low toxicity on Vero cell lines compared with other solvent extractions. Further work is required to investigate the methanolic extract potential and pathway for its anti-HSV-2 activity in terms of its mechanism in infected cells and global protein expression. 


\section{ACKNOWLEDGEMENTS}

The National Research Council of Thailand and the Graduate School, Chiang Mai University, Thailand supported this study. We are grateful to Department of Biology and Department of Chemistry, Faculty of Science, Chiang Mai University for providing the equipment and facilities.

\section{CONFLICT OF INTEREST STATEMENT}

The authors declare no conflict of interest.

\section{REFERENCES}

Antrobus, R., Grant, K., Gangadharan, B., Chittenden, D., Everett, R.D., Zitzmann, N., and Boutell, C. 2009. Proteomic analysis of cells in the early stages of herpes simplex virus type-1 infection reveals widespread changes in the host cell proteome. Proteomics. 9: 3913-3927. https://doi.org/10.1002/pmic.200900207

Benencia, F., and Courreges, M.C. 1999. Antiviral activity of sandalwood oil against herpes simplex viruses-1 and -2. Phytomedicine. 6(2): 119-123.

Brimson, M.J., and Tencomnao, T. 2011. Rhinacanthus nasutus protects cultured neuronal cells against hypoxia induced cell death. Molecules. 16: 6322-6338. https://doi.org/ 10.3390/molecules 16086322

Brimsom, M.J., Brimson, J.S., Brimson, A.C., Rakkhitawatthana, V., and Tencomnao, T. 2012. Rhinacanthus nasutus extracts prevent glutamate and amyloid- $\beta$ neurotoxicity in HT22 mouse hippocampal cells: possible active compounds include Lupeol, Stigmasterol and $\beta$-Sitosterol. International Journal of Molecular Sciences. 13: 5074-5097. https:// doi.org/10.3390/ijms13045074

Bourne, K.Z., Bourne, N., Reising, S.F., and Stanberry, L.R. 1999. Plant products as topical microbicide candidates: assessment of in vitro and in vivo activity against herpes simplex virus type 2. Antiviral Research. 42: 219-226. https://doi.org/10.1016/S01663542(99)00020-0

Chaliewchalad, P., Thongwai, N., and Tragoolpua, Y. 2013. Inhibitory effect of Rhinacanthus nasutus (Linn.) Kurz. and Stemona tuberosa (Lour.) extracts on herpes simplex virus infection. Journal of Medicinal Plants Research. 7(2): 76-84. https://doi.org/10.5897/ JMPR12.906

Dolan, A., Jamieson, E.F., Cunningham, C., Barnett, C.B., and McGeoch, J.D. 1998. The genome sequence of herpes simplex virus type 2. Journal of Virology. 72(3): 20102021.

Koch, C., Reichling, J., Schneele, J., and Schnitzler, P. 2008. Inhibitory effect of essential oils against herpes simplex virus type 2. Phytomedicine. 15: 71-78. https://doi. org/10.1016/j.phymed.2007.09.003

Kumar, N., Ganesan, C.M., and Paulsamy, S. 2012. Micropropagation of Rhinacanthus nasutus (Linn.) Kurz. - An important medicinal plant. Research \& Reviews: Journal of Botanical Sciences. 1(1): 5-10. 
Kumar, P., Venkatachalam, T., Suresh, H.C., Anvitha C., and Lalitha, J.K. 2011. Anti-ulcer evaluation of methanolic extract of Rhinacanthus nasutus (Linn.) Kurz. IJAPBS. 2(3): 1225-1228.

Kunsorn, P., Ruangrungsi, N., Lipipun, V., Khanboon, A., and Rungsihirunrat, K. 2013. The identities and anti-herpes simplex virus activity of Clinacanthus nutans and Clinacanthus siamensis. Asian Pacific Journal of Tropical Biomedicine. 3(4): 284-290. https://doi.org/10.1016/S2221-1691(13)60064-7

Mathew, S.S., Bryant, W.P., and Burch, D.A. 2010. Accumulation of oxidized proteins in Herpesvirus infected cells. Free Radical Biology and Medicine. 49: 383-391. https:// doi.org/10.1016/j.freeradbiomed.2010.04.026

McDade, L.A., Daniel, T.F., Kiel, C.A., and Vollesen, K. 2005. Phylogenetic relationships among Acantheae (Acanthaceae): Major lineages present contrasting patterns of molecular evolution and morphological differentiation. Systematic Botany. 30(4): 834-862.

McDade, L.A., Masta, S.E., Moody, M.L., and Waters, E. 2000. Phylogenetic relationships among Acanthaceae: Evidence from two genomes. Systematic Botany. 25(1): 106-121.

Mossman, T. 1983. Rapid colorimetric assay for cellular growth and survival: Application to proliferation and cytotoxicity assay. Immunological Communications. 65: 55-63.

Nakama, S., Tamaki, K., Ishikawa, C., Tadano, M., and Mori, N. 2012. Efficacy of Bidens Pilosa extract against herpes simplex virus infection in vitro and in vivo. Evidence-Based Complementary and Alternative Medicine. p. 1-10. https://doi.org/ $10.1155 / 2012 / 413453$

Nolkemper, S., Reichling, J., Sennsch, H.K., and Schnitzler, P. 2010. Mechanism of herpes simplex virus type suppression by propolis extracts. Phytomedicine. 17: 132-138. https://doi.org/10.1016/j.phymed.2009.07.006

Rao, V.P., Madhavi, K., Naidu, D.M., and Gan, H.S. 2013. Rhinacanthus nasutus improves the levels of liver carbohydrate, protein, glycogen, and liver markers in Streptozotocininduced diabetic rats. Evidence-Based Complementary and Alternative Medicine. p. 1-7. https://doi.org/ 10.1155/2013/102901

Reynolds, S.J., Risbud, A.R., Shepherd, M.E., Zenilman, J.M., Brookmeyer, R.S., and Paranjape, R.S. Divekar, A.D., Gangakhedkar, R.R., Ghate, M.V., Bollinger, R.C., et al. 2003. Recent herpes simplex virus type 2 infection and the risk of human immunodeficiency virus type 1 acquisition in India. Journal of Infectious Diseases. 187(10): 1513-1521. https://doi.org/10.1086/368357

Schomogyi, M., Wald, A., and Corey, L. 1998. Herpes simplex virus-2 infection. An emerging disease? Infectious Disease Clinics of North America. 12(1): 47-61.

Stanberry, L., Cunningham, A., Mertz, G., Mindel, A., Peters, B., Reitano, M., Sacks, S., Wald, A., Wassilew, S., and Woolley, P. 1999. New developments in the epidemiology, natural history and management of genital herpes. Antiviral Research. 42(1): 1-14. https://doi.org/10.1016/S0166-3542(99)00004-2

Straface, G., Selmin, A., Zanardo, V., De Santis, M., Ercoli, A., and Scambia, G. 2012. Herpes simplex virus infection in pregnancy. Infectious Diseases in Obstetrics and Gynecology. p. 1-6. https://doi.org/10.1155/2012/385697 
Suman, B., Raghu, P.S., Sailaja, G., and Thyaga, R.K. 2011. The study on morphological and pharmacological aspects of Rhinacanthus nasutus (L) Kurz. Journal of Applied Pharmaceutical Sciences. 1(8): 26-32.

Taylor, T.J., Brockman, M.A., McNamee, E.E., and Knipe, D.M. 2002. Herpes simplex virus. Frontiers in Bioscience. 7: 752-764.

Whitley, R.J., Kimberlin, D.W., and Roizman, B. 1998. Herpes simplex viruses. Clinical Infectious Diseases. 26(3): 541-553.

Xiong, H-R., Luob, J., Houa, W., Xiaoa, H., and Yanga, Z-Q. 2011. The effect of emodin, an anthraquinone derivative extracted from the roots of Rheum tanguticum, against herpes simplex virus in vitro and in vivo. Journal of Ethnopharmacology. 133: 718-723. https://doi.org/10.1016/j.jep.2010.10.059

Yang, C.M., Cheng, H.Y., Lin, T.C., Chiang, L.C., and Lin, C.C. 2005. Acetone, ethanol and methanol extracts of Phyllanthus urinaria inhibit HSV-2 infection in vitro. Antiviral Research. 67(1): 24-30. https://doi.org/10.1016/j.antiviral.2005.02.008

Yoosook, C., Bunyapraphatsara, N., Boonyakiat, Y., and Kantasuk, C. 2000. Anti-herpes simplex virus activities of crude water extracts of Thai medicinal plants. Phytomedicine. 6(6): 411-419. https://doi.org/10.1016/S0944-7113(00)80068-9

Yoosook, C., Panpisutchaia, Y., Chaichanab, S., Santisukc, T., and Reutrakulb, V. 1999. Evaluation of anti-HSV-2 activities of Barleria lupulina and Clinacanthus nutans. Journal of Ethnopharmacology. 67(2): 179-187. https://doi.org/10.1016/S03788741(99)00008-2 